\title{
Effect of ceramide on apoptosis and phospholipase D activity in FRTL-5 thyroid cells
}

\author{
Byung-Jun Park', Jong-Hoon Kim ${ }^{2,3}$, \\ Joong-Soo $\mathrm{Han}^{2,3,5}$ and Poong-Man Jung ${ }^{4}$ \\ ${ }^{1}$ Department of General Surgery, College of Medicine, \\ Sung Kyun Kwan University, Seoul 100-380, Korea \\ ${ }^{2}$ Department of Biochemistry, College of Medicine, \\ Hanyang University, Seoul 133-791, Korea \\ ${ }^{3}$ Institute of Biomedical Science, Hanyang University, \\ Seoul 133-791, Korea \\ ${ }^{4}$ Department of General Surgery, College of Medicine, \\ Hanyang University, Seoul 133-791, Korea \\ ${ }^{5}$ Corresponding author: Tel, +82-2-2290-0623; \\ Fax, +82-2-2294-6270; E-mail, jshan@email.hanyang.ac.kr
}

Accepted 5 July 1999

Abbreviations: PC, phosphatidylcholine; PEt, phosphatidylethanol; PLD, phospholipase D; TSH, thyroid-stimulating hormone

\begin{abstract}
Ceramide, a product of sphingomyelin hydrolysis, is now recognized as an intracellular lipid messenger, which mediates the effects of extracellular agents on cellular growth, differentiation and apoptosis. Recently, ceramide has been implicated in the regulation of phospholipase $D$ (PLD). In this study, we examined the effects of ceramide on the activity and mRNA level of PLD during apoptotic process in FRTL-5 thyroid cells. $\mathrm{C}_{2}$-ceramide ( $\mathrm{N}$-acetyl sphingosine) induced apoptosis in FRTL- 5 thyroid cells. Fluorescent staining showed that ceramide induced the typical features of apoptosis including condensed or fragmented nuclei. DNA fragmentation was also observed by agarose gel electrophoresis. Flow cytometric cell cycle analysis showed more clearly that ceramide induced apoptotic cell death in FRTL-5 thyroid cells. The treatment of FRTL-5 thyroid cells with thyroid-stimulating hormone (TSH) resulted in an increased PLD activity in a dose- and time-dependent manner. However, the TSH-induced increase in PLD activity was down-regulated within $2 \mathrm{~h}$ after ceramide treatment. Furthermore, the levels of PLD mRNA were found to be decreased throughout apoptotic process as inferred by reverse transcription-polymerase chain reaction. However, the decreases in PLD mRNA levels were not correlated with those in PLD activities
\end{abstract}

after ceramide treatment. Taken together, these data suggest that ceramide inhibits the PLD activity in an early apoptotic phase and down-regulation of the levels of PLD mRNA may be implicated in apoptotic process in FRTL-5 thyroid cells.

Keywords: ceramide, apoptosis, thyroid-stimulating hormone, phospholipase D, FRTL- 5 thyroid cells

\section{Introduction}

Signal transduction system generating phospholipid metabolites constitutes one of the most important systems for the generation of second messenger to regulate cell growth. Phospholipase D (PLD) plays a key role in signal transduction and its activation occurs in a wide range of cell types in response to hormones and growth factors and is implicated in the regulation of inflammatory and immune response, cellular trafficking, and cell growth (Exton, 1994). PLD catalyzes the hydrolysis of cell phospholipid, mainly phosphatidylcholine (PC), resulting in the formation of phosphatidic acid (PA), which acts by itself as cellular messenger (Exton, 1990) or can be transformed by PA phosphohydrolase into diacylglycerol (DAG), which is essential for the activation of protein kinase C (PKC) (Nishizuka, 1995).

Programmed cell death or apoptosis is a process of active cellular self-destruction that plays an indispensable role in the development and maintenance of homeostasis in multicellular organisms (Clarke, 1990). Its hallmark biochemical feature is endonuclease activation, giving rise to DNA fragmentation (Wyllie et al., 1980). There are also characteristic morphologic changes, including chromatin condensation, nuclear fragmentation and shrinkage, and the formation of dense chromatin masses (apoptotic body) (Wyllie et al., 1980; Morris et al., 1984; Stacey et al., 1985). Recent investigations indicate that signaling events following cellular exposure to tumor necrosis factor $\alpha$ (TNF $\alpha$ ), Fas ligand, glucocorticoids, irradiation and other DNAdamaging agents seem to converge in intracellular signals that result in apoptosis (Arends and Wyllie, 1991; Williams and Smith, 1993; Hoffman and Liebermann, 1994; Wyllie, 1995)

Ceramide has recently emerged as an important intracellular mediator for cell growth, differentiation and programmed cell death in a growing number of cell 
types (Hannun and Obeid, 1995; Kolensnick and Fuks, 1995; Testi, 1996). Ceramide biosynthesis is initiated by hydrolysis of the phospholipid, sphingomyelin, which is preferentially localized to the outer leaflet of the plasma membrane (Spiegel et al., 1996). Cellular exposure to TNF $\alpha$, Fas ligand, irradiation, and other DNA-damaging agents may trigger apoptosis via the hydrolysis of membrane sphingomyelin generating ceramide (Bielawska et al., 1993; Haimovitz-Freidman et al., 1994; Kolesnick et al., 1994; Gamen et al., 1996). However, the apoptotic effects of TNF $\alpha$ and ceramide are inhibited by simultaneous addition of phorbol esters or DAG which are activators of PKC (Obeid et al., 1993; Jarvis et al., 1994). The opposing effects of ceramide and DAG on viability/apoptosis suggest that the decision of cells to live or die may be a result of the relative contribution of at least two distinct signal transduction pathways involving DAG and ceramide, respectively. It is well known that DAG can be generated by the rapid conversion of PA produced by PLD acting on PC as well as from phosphoinositide (PI) by PI-specific phospholipase C (Liscovitch, 1991; Venable et al., 1994). Furthermore, accumulating evidences show that the action of PC-PLD followed by PA phosphohydrolase results in more sustained DAG production (Liscovitch, 1991). Recently, it has been also reported that $C_{2-}$ ceramide inhibited PLD activity in rat basophilic leukemia cells (Nakamura et al., 1996), in rat fibroblast (Gomez-Munoz et al., 1994; Jones and Murray, 1995), and in cell-free systems using HL-60 cells (Venable et al., 1996). C $_{6}$-ceramide also inhibited PLD activity and DAG accumulation in human diploid fibroblast (Venable et al., 1994). However, to our knowledge, no reports have been available about ceramide-induced apoptosis and effect of ceramide on PLD activity in thyroid cell. In thyroid cells, apoptosis is suspected of being involved in the regulation of normal glandular size and appears to be one of the major modes of thyrocyte death in autoimmune thyroid disease (Kotani et al., 1995; Tanimoto et al., 1995). With these premises, in the present study we have examined the effects of ceramide on apoptotic cell death and the possibility that PLD may be involved in apoptotic cell death in FRTL-5 thyroid cells.

\section{Materials and Methods}

\section{Materials}

FRTL-5 thyroid cells were purchased from American type culture collection (ATCC; Rockville, MD, U.S.A.). Coon's modified Ham's F-12 medium, human transferrin, bovine insulin, hydrocortisone, somatostatin, glycylL-histidyl-L-lysine, bovine serum albumin, TSH, primulin, acridine orange staining dye and propidium iodide were purchased from Sigma Chemical Co. (St. Louis, MO,
U.S.A.). $\mathrm{C}_{2}$-ceramide (N-Acetyl sphingosine) was from Biomol (Plymouth meeting, PA, U.S.A.). $\left[{ }^{3} \mathrm{H}\right]$-myristate was obtained from Du Pont-New England Nuclear (Boston, MA, U.S.A.). Newborn calf serum and penicillin/streptomycin solution were purchased from GibcoBRL (Gaithersburg, MD, U.S.A.). TLC plates of silica gel 60 were obtained from Merck (Baltimore, MD, U.S.A.). Taq DNA polymerase and Oligo(dT)-primers were purchased from Takara shuzo (Ohtsu, Japan). All other chemicals were obtained from commercial sources and were of analytical grade.

\section{Cell culture}

FRTL-5 thyroid cells were cultured in Coon's modified Ham's F-12 medium supplemented with $5 \%$ newborn calf serum and six-hormone mixture $(6 \mathrm{H})$ comprised of bovine insulin $(10 \mu \mathrm{g} / \mathrm{ml})$, hydrocortisone $(0.36 \mathrm{ng} / \mathrm{ml})$, human transferrin $(5 \mu \mathrm{g} / \mathrm{ml})$, glycyl-L-histidyl-L-lysine acetate $(10 \mu \mathrm{g} / \mathrm{ml})$, somatostatin $(10 \mu \mathrm{g} / \mathrm{ml})$, and TSH $(2$ $\mathrm{mU} / \mathrm{ml}$ ), as previously described (Mori et al., 1996). Cells were maintained at $37^{\circ} \mathrm{C}$ in an atmosphere saturated with water and containing $95 \%$ air- $5 \% \mathrm{CO}_{2}$. When confluence was reached, cells were trypsinized and subcultured to 6-well tissue culture plates. After the cells reached to confluence, the medium was changed to $5 \mathrm{H}$ medium (6H medium devoid of $\mathrm{TSH})$, and the cells were incubated for a further 6 days. The culture medium was changed twice weekly. On the day of the experiment, the medium was replaced with Coon's modified Ham's F-12 medium without any additional hormones.

\section{Fluorescent staining of apoptotic nuclei}

After the indicated incubation periods, the cells were treated with mild hypertonic solution (distilled water: PBS; $1: 1, \mathrm{v} / \mathrm{v}$ ) for $10 \mathrm{~min}$. The cells were prefixed in $50 \%$ solution of fixative (methanol : acetic acid; $3: 1, \mathrm{v} /$ v) for $5 \mathrm{~min}$ and followed by fixation for $10 \mathrm{~min}$. After fixation, the cells were stained with acridine orange (1 $\mu \mathrm{g} / \mathrm{ml})$ for $10 \mathrm{~min}$. The stained cells were rinsed and observed with a fluorescence microscope (Diaphot 300 attached with epi-fluorescence, Nikon).

\section{DNA fragmentation analysis}

Equivalent number $\left(10^{5}\right)$ of cells were seeded into each well of 6 well plates and grown in $6 \mathrm{H}$ medium. After the indicated incubation periods, the total cell population (adherent and detached cells) were collected and lysed in $1 \mathrm{ml}$ of $100 \mathrm{mM} \mathrm{NaCl}, 10 \mathrm{mM}$ Tris- $\mathrm{HCl} \mathrm{pH} \mathrm{8.0,25} \mathrm{mM}$ EDTA, $0.5 \%$ SDS. Lysates were incubated for $4 \mathrm{~h}$ at $56^{\circ} \mathrm{C}$ with $0.2 \mathrm{mg} / \mathrm{ml}$ proteinase $\mathrm{K}$. After extraction with equal volume of phenol/chloroform/isoamyl alcohol (25: $24: 1, \mathrm{v} / \mathrm{v})$, followed by re-extraction with chloroform/ isoamyl alcohol $(24: 1, \mathrm{v} / \mathrm{v})$. DNA was precipitated by addition of 0.1 volume of $3 \mathrm{M}$ sodium acetate, $\mathrm{pH} 5.3$, and one volume of isopropanol and incubation at $-70^{\circ} \mathrm{C}$ 
for at least $1 \mathrm{~h}$. Precipitated DNA was collected by centrifugation at $14,000 \mathrm{~g}$ for $30 \mathrm{~min}$ at $4^{\circ} \mathrm{C}$, washed with ice-cold $80 \%$ ethanol and air-dried. DNA was then resuspended in $10 \mathrm{mM}$ Tris- $\mathrm{HCl}, \mathrm{pH} 7.5,1 \mathrm{mM}$ EDTA (TE buffer) and treated with $0.5 \mathrm{mg} / \mathrm{ml}$ RNase at $37^{\circ} \mathrm{C}$. DNA samples were fractionated by electrophoresis in a $1.5 \%$ TBE-agarose gel at $100 \mathrm{~V}$ and visualized by ethidium bromide staining.

\section{Flow cytometric analysis}

Cells were treated with $50 \mu \mathrm{M} \mathrm{C}_{2}$-ceramide or ethanol (vehicle) for $12 \mathrm{~h}$. Cells were then harvested by trypsinization, washed once in PBS and fixed with ice-cold $70 \%$ ethanol at $4^{\circ} \mathrm{C}$ for $30 \mathrm{~min}$. Fixed cells were stained in $1 \mathrm{ml}$ of propidium iodide $(50 \mu \mathrm{g} / \mathrm{ml})$ in PBS containing $0.1 \%$ Trition X-100, $0.1 \mathrm{mM}$ EDTA $(\mathrm{Na})_{2}$, and $50 \mu \mathrm{g} / \mathrm{ml}(50 \mathrm{U} / \mathrm{mg})$ of DNase-free RNase and subject-ed to flow cytometry on a FACScan (Becton-Dickinson, NJ, U.S.A.) using CELL Quest ${ }^{\mathrm{TM}}$ software.

\section{Determination of PLD activity}

PLD activity was determined by measuring the accumulation of $\left[{ }^{3} \mathrm{H}\right]$-phosphatidylethanol (PEt), since this is the product of its transphosphatidylation reaction which is considered to be a definitive assay for PLD (Exton, 1990). FRTL-5 thyroid cells were washed three times with modified Ham's F-12 medium and then incubated in serum-free modified Ham's F-12 medium containing $0.1 \%$ albumin and $2 \mu \mathrm{Ci} /$ well of $\left[{ }^{3} \mathrm{H}\right]$-myristate for $4 \mathrm{~h}$. The reaction medium was aspirated, and the cells were washed twice with nonradioactive Ham's mediumalbumin solution. The FRTL-5 thyroid cells were then incubated for a further $2 \mathrm{~h}$ in medium containing $0.5 \%$ albumin with three changes of medium. The medium was then replaced with medium containing $0.1 \%$ albumin and $1 \%(\mathrm{v} / \mathrm{v})$ ethanol. TSH at the indicated concentration was added after $5 \mathrm{~min}$ incubation, and the cells were incubated for the times specified. To determine the effect of ceramide on TSH-mediated PLD activity, the cells were pretreated with various concentrations of ceramide for the indicated times and then treated TSH in the presence of $1 \%$ ethanol. Incubation was performed at $37^{\circ} \mathrm{C}$ and terminated by washing the cells twice with ice-cold PBS and immediately adding $0.5 \mathrm{ml}$ of ice-cold methanol. Cells were collected by scraping and the dishes were washed with an additional $0.5 \mathrm{ml}$ of ice-cold methanol. Lipids were then extracted essentially as described by Bligh and Dyer (1959), and PEt was separated from other phospholipids by thin layer chromatography (TLC) on silica gel 60 plates with the organic phase of the solvent system: ethyl acetate/ 2,2,4-trimethylpenthan/acetic acid/water (110:50:20 : $100, v / v)$. Unlabeled PEt was run together with samples and the corresponding lipid spot was identified by exposure to $0.002 \%(\mathrm{w} / \mathrm{v})$ primulin in $80 \%(\mathrm{v} / \mathrm{v})$ ace- tone, scraped and then counted using a scintillation counter.

\section{RNA extraction and RT-PCR}

Total cellular RNA was isolated using RNAzol ${ }^{\mathrm{TM}}$ (Biotecx Lab, TX, U.S.A.), according to the manufacturer's instruction. RNA $(2.5 \mu \mathrm{g})$ was subjected to CDNA synthesis using avian myoblastosis virus (AMV) reverse transcriptase (Promega, WI, U.S.A) in the supplied buffer system and oligo(dT)-primer. Synthesis was performed at $42^{\circ} \mathrm{C}$ for 60 min followed by denaturation of the cDNA strands at $95^{\circ} \mathrm{C}$ for $5 \mathrm{~min}$. Samples were cooled rapidly to $4^{\circ} \mathrm{C}$ and $2-4 \mu \mathrm{l}$ were used for PCR. RTPCR was performed using Taq DNA polymerase (TaKaRa Shuzo, Japan) in the supplied buffer system with $0.2 \mathrm{mM}$ dNTP mixture and relevant primers. PCR primer set for PLD was 5'-CGGTGGCGTTTGTGGGTGGGA-3' (sense) and 5'-GTCCTTGAAGACAAAGTTG$C A-3^{\prime}$ (antisense). The PCR primer set for $\beta$-actin was 5'-TTGATACCAACTGGGACGATATGG-3' (sense) and 5'-GATCTTGATCTTCATGGTGCTAGG-3' (antisense). Temperatures used for PCR were as follows: for PLD, denaturation at $94^{\circ} \mathrm{C}$ for $30 \mathrm{sec}$; annealing at $58^{\circ} \mathrm{C}$ for 1 $\mathrm{min}$; and extension at $72^{\circ} \mathrm{C}$ for $1 \mathrm{~min}$, for $\beta$-actin, denaturation at $94^{\circ} \mathrm{C}$ for $1 \mathrm{~min}$; annealing at $60^{\circ} \mathrm{C}$ for 1 $\mathrm{min}$; and extension at $72^{\circ} \mathrm{C}$ for $1 \mathrm{~min}$, respectively. Numbers of amplification cycles were determined for individual primer sets to maintain exponential rate of product amplification. The number of cycles determined for $\beta$-actin was 30 , for PLD was 28 , respectively. Amplified DNA fragments were subjected to electrophoresis on $1.5 \%$ agarose gel and visualized by ethidium bromide staining. Intensity of bands was quantified by a densitometry.

\section{Results}

\section{Ceramide induced apoptotic cell death in FRTL-5 thyroid cells}

To ascertain whether ceramide initiates an apoptotic response in FRTL-5 thyroid cells, experiment was carried out using the synthetic ceramide analogue $\mathrm{C}_{2-}$ ceramide (N-acetyl sphingosine). Incubation of FRTL-5 thyroid cells for $12 \mathrm{~h}$ with $50 \mu \mathrm{M} \mathrm{C}_{2}$-ceramide produced typical apoptotic changes of nuclear condensation, fragmentation, and apoptotic body formation, detected by staining with fluorescent dye, acridine orange (Figure 1). In addition to the typical morphological changes, ceramide-induced apoptosis in FRTL- 5 thyroid cells was also demonstrated by agarose gel electrophoresis of DNA extracted from treated cells. Treatment with $50 \mu \mathrm{M}$ $\mathrm{C}_{2}$-ceramide produced a typical ladder pattern of oligonucleosomal fragments (Figure 2). To identify the subpopulation of FRTL-5 thyroid cells undergoing apoptosis, flow cytometry was performed in cells stained 

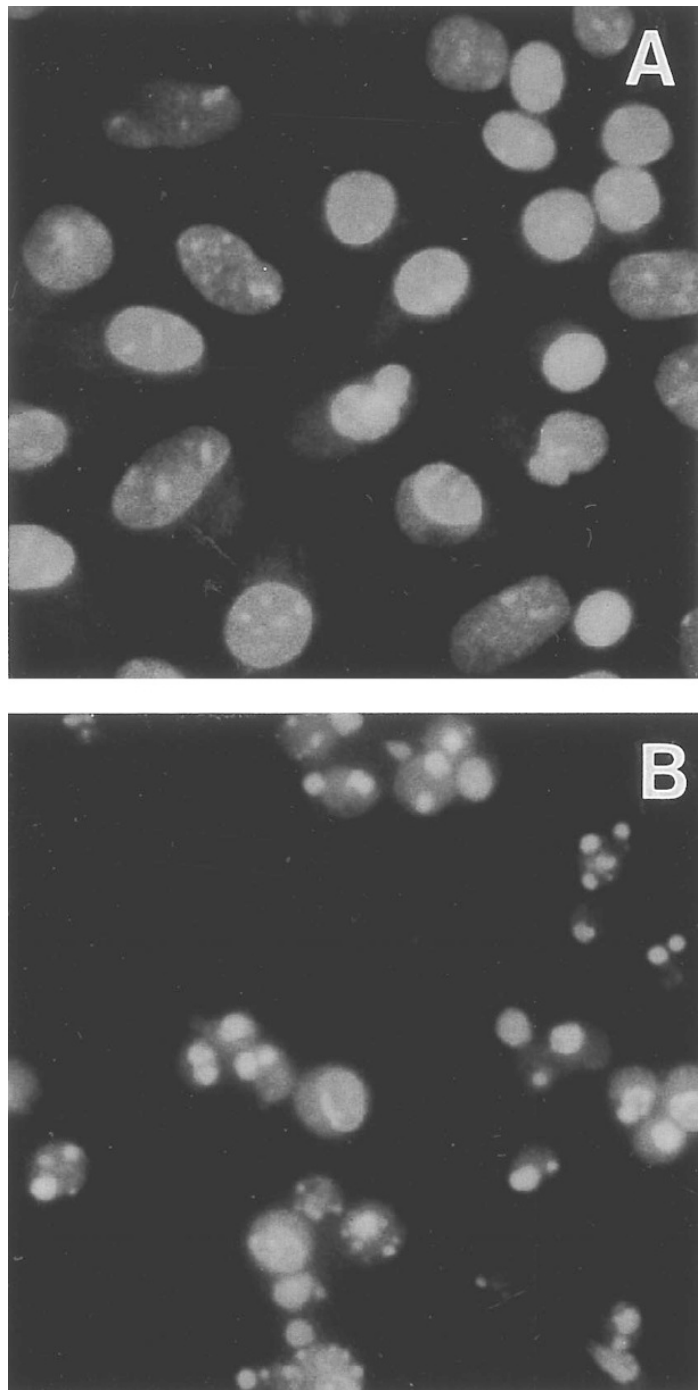

Figure 1. Morphological change after treatment of $\mathrm{C}_{2}$-ceramide. Untreated FRTL-5 thyroid cells (A), or the cells treated with $50 \mu \mathrm{M} \mathrm{C}$-ceramide (B), were fixed after $12 \mathrm{~h}$ in culture with methanol:acetic acid $(3: 1, \mathrm{v} / \mathrm{v})$ and stained with fluorescent dye, acridine-orange ( $0.01 \%$ in PBS). Note the typical morphological features of apoptosis, including nuclear condensation, chromatin fragmentation, and apoptotic body in B.

with propidium iodide. This method makes it possible to correlate the presence of fluorescing DNA breaks in individual cells with their DNA ploidy and position in the cell cycle. Control cells incubated for $12 \mathrm{~h}$ under the same culture conditions had DNA ploidy of $A_{0}$ phase in $7.38 \%$ of the cells (Figure 3 ). On the other hand, treatment with $50 \mu \mathrm{M} \mathrm{C}_{2}$-ceramide for $12 \mathrm{~h}$ resulted in the appearance of cells exhibiting apoptotic DNA fragmentation and $37.6 \%$ of the total population of treated cells showed apoptotic fluorescence $\left(A_{0}\right)$. These data clearly demonstrated that ceramide induced apoptotic cell death in FRTL-5 thyroid cells.

\section{Effect of ceramide on TSH-induced PLD activity}

12

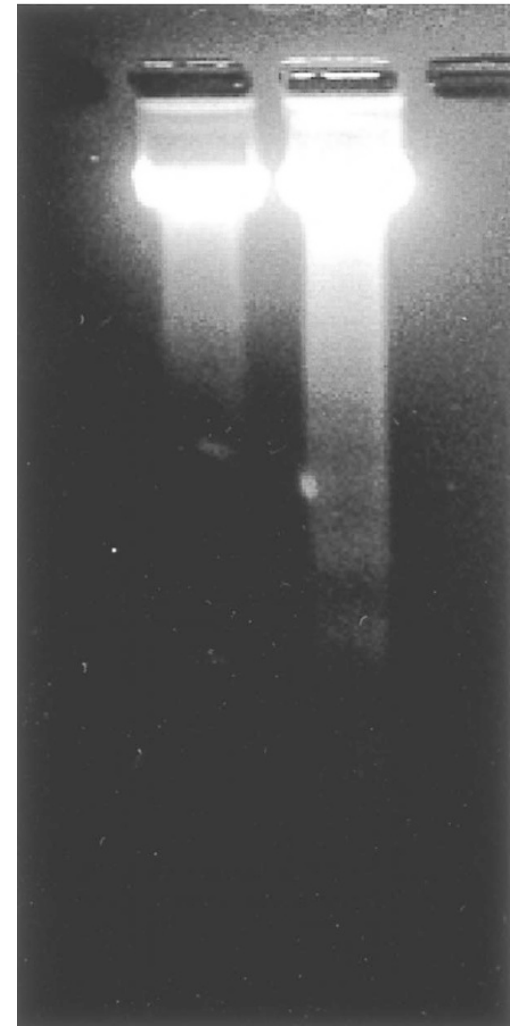

Figure 2. Agarose gel electrophoresis of DNA from cells treated for $12 \mathrm{~h}$ with $50 \mu \mathrm{M} \mathrm{C}_{2}$-ceramide or vehicle only. After $12 \mathrm{~h}$ of treatment, FRTL- 5 thyroid cells were lysed, and the total DNA was extracted as described in Materials and Methods. The fragmented DNA was analyzed on $2.0 \%$ agarose gel electrophoresis. Lane 1, control cells; Lane 2, $\mathrm{C}_{2}$-ceramide $(50 \mu \mathrm{M})$ treated cells.

It has been reported that TSH induces thyroid growth and differentiation via metabolic pathway controlling the activity of PLD (Lejeune et al., 1996). First of all, to determine whether TSH increases the PLD activity, FRTL-5 thyroid cells were incubated with TSH $(100 \mu \mathrm{U} /$ $\mathrm{ml}$ ) and the PLD activities after various times of exposure were monitored (Figure 4). A significant change of PLD activity was seen as early as $10 \mathrm{~min}$ after exposure to TSH. PLD activity was significantly increased after TSH treatment at each time point examined, with maximal response after $120 \mathrm{~min}$ exposure to TSH. In addition to these results, a doseresponse curve for TSH revealed maximum PLD activity at $100 \mu \mathrm{U} / \mathrm{ml}$ TSH compared to control values (Figure 5).

To determine the modulatory role of ceramide on the action of TSH in PLD activation, the effect of $\mathrm{C}_{2-}$ ceramide $(0-50 \mu \mathrm{M})$ on the stimulation of PLD activity by TSH was then evaluated in FRTL-5 thyroid cells. As shown in Figure 6, TSH-induced PLD activity was not significantly affected at $1 \mathrm{~h}$ after ceramide treatment except for $50 \mu \mathrm{M} \mathrm{C}_{2}$-ceramide. On the other hand, 

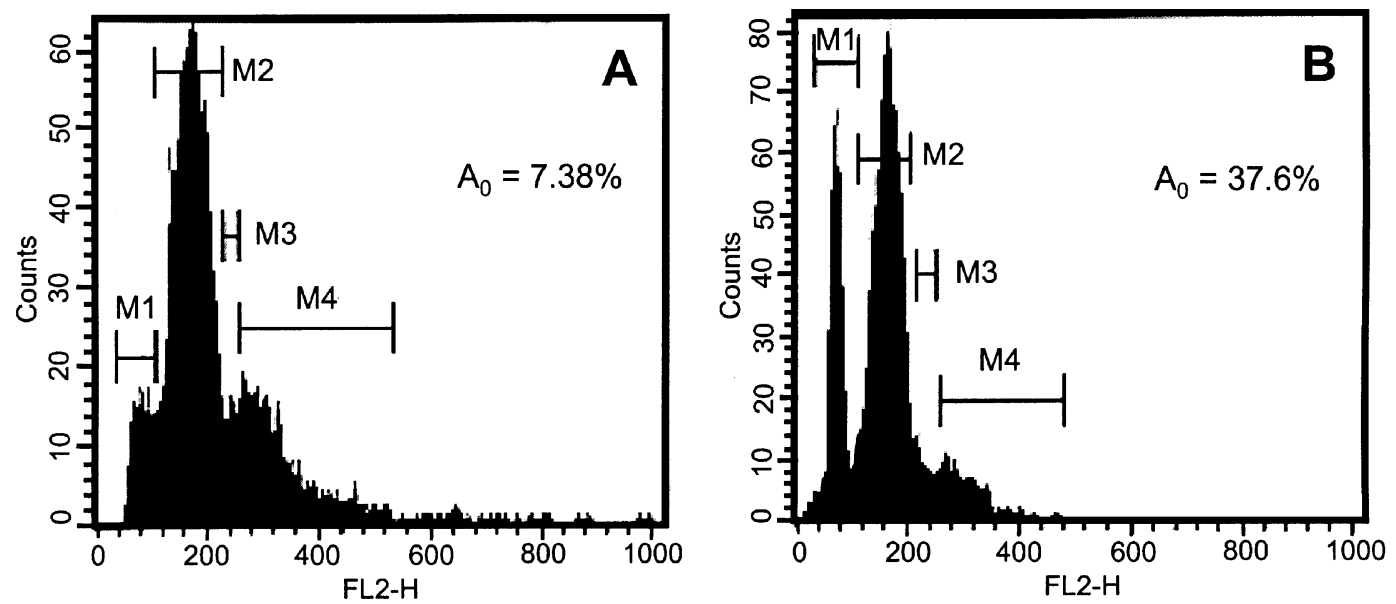

Figure 3. Detection of ceramide-induced apoptotic DNA breaks in FRTL-5 thyroid cells by flow cytometric analysis. FRTL-5 thyroid cells were treated with vehicle $(A)$ or $50 \mu \mathrm{M} \mathrm{C}_{2}$-ceramide $(B)$ for $12 \mathrm{~h}$. The percentage of cells containing sub-diploid amount of DNA ( $A_{0}$ cells) and the distribution of cells in cell cycle were determined by DNA fluorescence flow cytometry of propidium iodide-stained cells. Region M1 represents the portion of cell population containing subdiploid levels of DNA $\left(A_{0}\right)$. Region $M 2, M 3$, and $M 4$ represents the $G_{0} / G_{1}, S$, and $G_{2} / M$ phase of cell cycle, respectively.

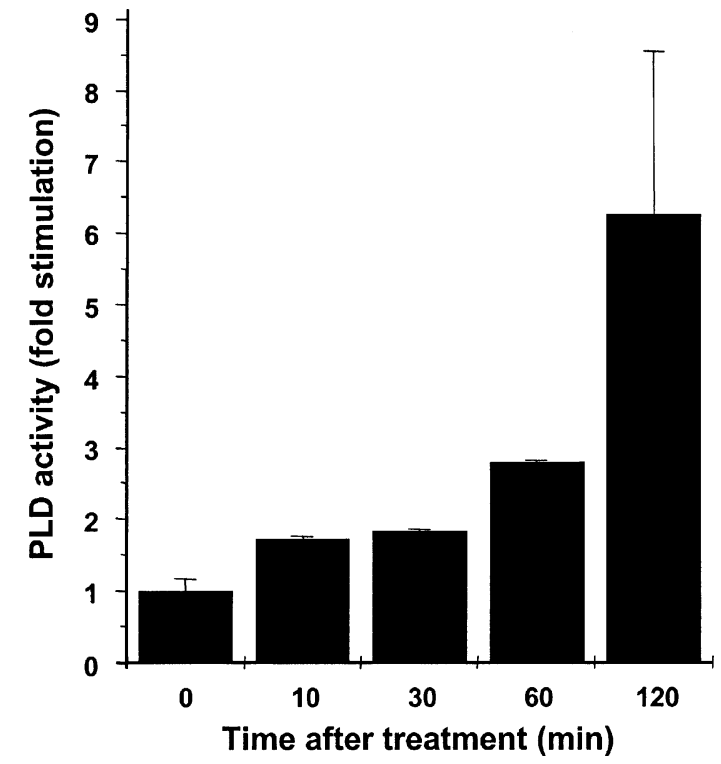

Figure 4. The effect of TSH on PLD activity. FRTL-5 thyroid cells were labeled with $\left[{ }^{3} \mathrm{H}\right]$ - myristate and then treated in the presence of ethanol with $100 \mu \mathrm{U} / \mathrm{ml}$ TSH for indicated time. The $\left.{ }^{3} \mathrm{H}\right]-\mathrm{PEt}$ bands were separated by thin layer chromatography, scraped and counted using liquid scintillation counter. The results were expressed as the fold stimulation relative to control and are given as the means $\pm S E$ of the experiment performed in triplicate.

ceramide substantially suppressed the PLD activity at 2 $\mathrm{h}$ after exposure. These results indicated that TSH could stimulate PLD activity and the TSH-induced PLD activation was perturbed completely by ceramide within $2 \mathrm{~h}$ after treatment.

\section{Changes in mRNA expression of PLD}

Because TSH-induced increase of PLD activity was decreased in an early phase of ceramide-induced apoptosis, we also examined the changes of gene

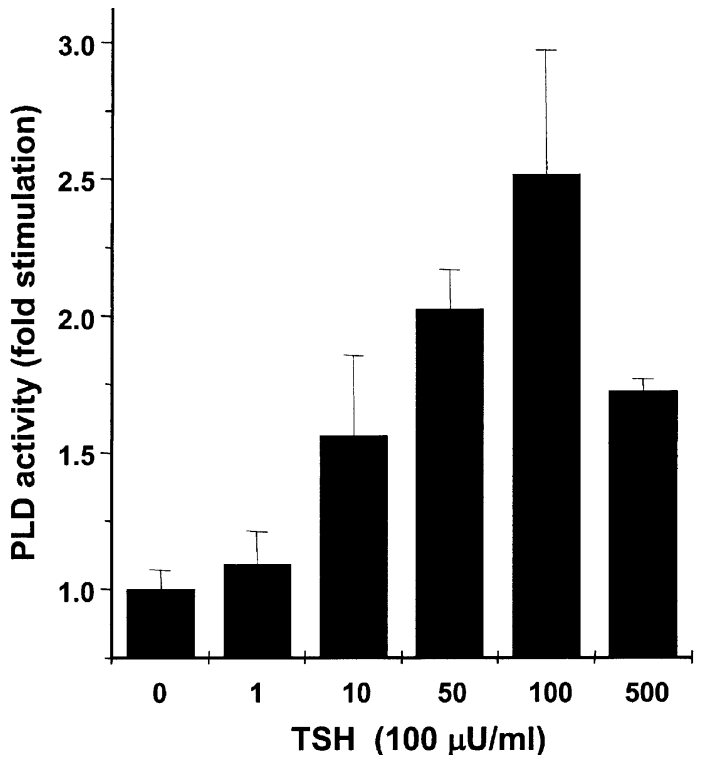

Figure 5. Effects of TSH concentration on PLD activation. FRTL-5 thyroid cells were labeled with $\left[{ }^{3} \mathrm{H}\right]$-myristate and then treated in the presence of ethanol with the concentration of TSH indicated for $1 \mathrm{~h}$ before the measurement of relative PLD activity. The PLD activity was determined by the measurement of $\left[{ }^{3} \mathrm{H}\right]-\mathrm{PEt}$ formation, and expressed as the fold stimulation relative 0 time. Results are the mean $\pm S E$ from the experiment performed in triplicate.

expression for PLD by RT-PCR throughout the apoptotic process. No significant changes were observed in levels of $\beta$-actin mRNA (reference control) throughout the time course (Figure 7), whereas the treatment of ceramide $(50 \mathrm{mM})$ decreased mRNA levels of PLD in a timedependent manner. The temporal profile of TSHdependent PLD activity, however, was not correlated with those of the mRNA levels of PLD after exposure to ceramide. 


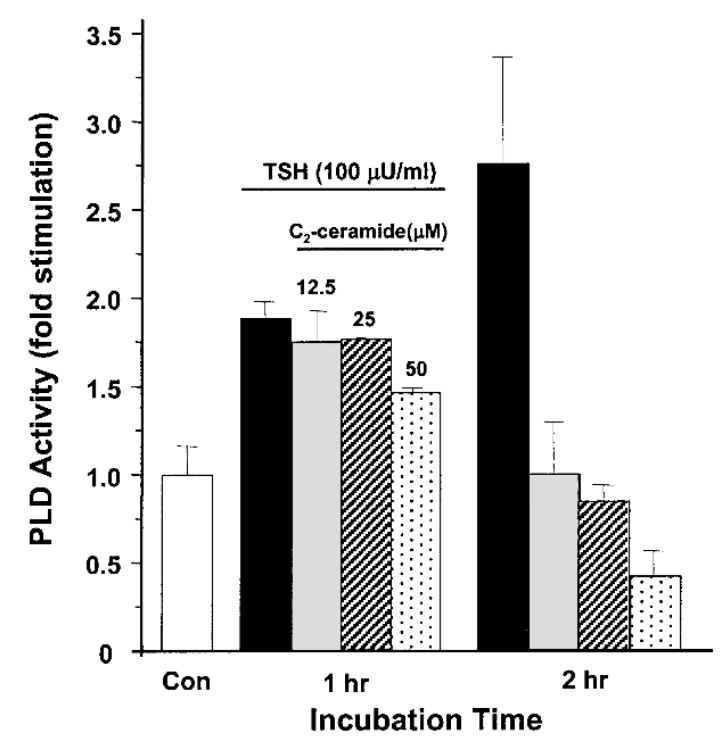

Figure 6. Changes of TSH-induced PLD activity in ceramide-treated FRTL-5 thyroid cells. FRTL-5 thyroid cells were labeled with $\left[{ }^{3} \mathrm{H}\right]$-myristate and then incubated with various concentration of $\mathrm{C}_{2}$-ceramide for the indicated period of time. The FRTL-5 thyroid cells were then treated for $10 \mathrm{~min}$ with $100 \mu \mathrm{U} / \mathrm{ml} \mathrm{TSH}$ in the presence of ethanol and $\mathrm{C}_{2}$-ceramide. PLD activities were determined through the formation of $\left[{ }^{3} \mathrm{H}\right]-\mathrm{PEt}$. The result was expressed as the fold stimulation relative to the control (Con) which did not contain ceramide. Data represents means $\pm S E$ from the experiment performed in triplicate.

\section{Discussion}

In the last few years, experimental evidence has been provided for a signaling role exerted by sphingoid molecules including ceramide. Among the multiple pathways which are regulated by these substances, the control of PLD activity may represent a crucial step, in view of the ability of this enzyme to affect the levels of key lipid mediators such as PA and DAG (Exton, 1994; Nishizuka, 1995).

Sphingomyelin pathway has been claimed to be involved in the apoptotic process and ceramide, the product of sphingomyelin hydrolysis by sphingomyelinase, appears to be a functional mediator of this pathway (Hannun and Obeid, 1995; Ballou et al., 1996; Testi, 1996). In this present study, we demonstrated for the first time that ceramide induces apoptosis in FRTL-5 thyroid cells, although it has been known to induce apoptosis in hematopoietic cells, fibroblast (Obeid et al., 1993), neurons (Brugg et al., 1996) and reproductive cells (Kaipia et al., 1996; Witty et al., 1996). Drastic morphological changes were observed in ceramidetreated cells. Cellular processes were retracted gradually and cells became round when examined under a phase-contrast microscopy (Data not shown). In addition, typical apoptotic changes, such as nuclear fragmentation, chromatin condensation and apoptotic body formation, were observed by acridine-orange staining.

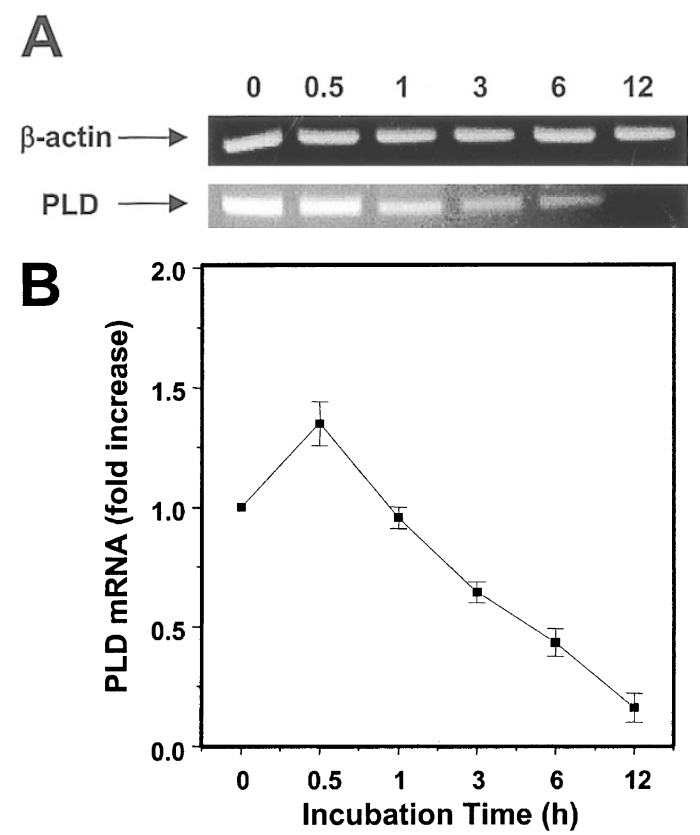

Figure 7. Changes in levels of PLD mRNAs in ceramide-treated FRTL-5 thyroid cells. Levels of mRNAs were analyzed by RT-PCR. After the treatment with $50 \mu \mathrm{M} \mathrm{C}_{2}$-ceramide, total RNA was isolated from FRTL-5 thyroid cells, at indicated times, with RNAzol ${ }^{\mathrm{TM}}$. RNA $(2.5 \mu \mathrm{g})$ was reverse transcribed using oligo(dT)-primers. Temperatures used for PCR were below: denaturation at $94^{\circ} \mathrm{C}$ for $30 \mathrm{sec}$; annealing at $58^{\circ} \mathrm{C}$ for $1 \mathrm{~min}$; and extension at $72^{\circ} \mathrm{C}$ for $1 \mathrm{~min}$. The number of amplification cycles determined for $\beta$-actin was 30 , for PLD was 28 , respectively to maintain the exponential rate of product amplification. Amplified DNA fragments were subjected to electrophoresis on $1.5 \%$ agarose gel and visualized by ethidium bromide staining (A). Intensity of bands was quantified by a densitometer and expressed as mean $\pm S E$ values from three different experiments $(B)$.

DNA fragmentation was confirmed by agarose gel electrophoresis. Flow cytometric analysis showed more clearly that ceramide induced apoptotic cell death in FRTL-5 thyroid cells. Recently, several studies demonstrated that apoptosis was involved in cell death of normal thyrocyte and thyroid diseases such as goiter (Tamura et al., 1998) and thyroiditis (Kotani et al., 1995), and also suggested that the mechanisms by which thyroid cells undergo apoptosis were mediated by Fas/Fas ligand system (Arscott et al., 1997; Tamura et al., 1998). In consideration of several findings indicating that sphingomyelin pathway is involved in Fasmediated apoptotic signaling in various type of cells (Gulbins et al., 1995; Tepper et al., 1997; Boesen-de Cock et al., 1998), our results also suggested that ceramide may play a role in Fas-mediated apoptosis in thyroid cells.

Recently, many investigators have demonstrated that ceramide inhibits PLD activity in a number of cells including rat basophilic leukemia cells (Nakamura et al., 1996), rat fibroblast (Gomez-Munoz et al., 1994; Jones and Murray, 1995) and C6 glial cells (Yoshimura et al., 1997). Because PLD activation is involved in cell 
proliferation and differentiation (Exton et al., 1994; Klein et al., 1995; Liscovitch and Cantley, 1995), it is tempting to examine that inhibition of PLD activity would be implicated in induction of apoptotic cell death by ceramide.

Our results showed that $\mathrm{TSH}$, a key growth factor for thyroid cell, induced an increase of PLD activity and that TSH-induced PLD activation was decreased with doseand time-dependent manners after addition of ceramide. These results indicated that the PLD pathway could be an important target for the modulation of signal transduction by ceramide. Although the exact mechanism of this effect is unclear at present, considering PLD activity is regulated by Arf, Rho (Bowman et al., 1993; Brown et al., 1993; Cockcroft et al., 1994; Malcolm et al., 1994) and PKC (Balboa et al., 1994), it is possible that ceramide may inhibit translocation of these PLD activator to membrane, leading to a decrease in PLD activity. In addition, it is well known that PA produced by PLD from PC may act as a potent mitogen in cells (Exton, 1994; Spiegel and Milstien, 1996). This is followed by DAG generation via a PA phosphohydrolase and then DAG activates PKC. Therefore, it is possible that ceramide-induced inhibition of PLD activity attenuates PA production and subsequent DAG accumulation, and results in insufficient PKC activation for cell growth. Accordingly, we propose that ceramide may play an important role in inhibiting mitogenic pathway in an early phase during apoptotic process.

We next examined expression of mRNAs of PLD in FRTL-5 thyroid cells treated with ceramide. Ceramide inhibited PLD gene expression in a time-dependent manner and mRNA of PLD was not detected by RTPCR at $12 \mathrm{~h}$ after exposure to ceramide. However, down-regulation of PLD gene expression was not correlated with ceramide-induced decreases in PLD activity. Therefore, decreased PLD activity might not be a result from decreased levels of PLD mRNA, and it is possible that these two events might be regulated by different mechanisms during ceramide-induced apoptotic process.

In summary, our results indicated that ceramide induced apoptotic changes in FRTL- 5 thyroid cell and also suggested that inhibition of PLD activity by ceramide might be involved in the induction of apoptotic process. Moreover, our results demonstrated that mRNA levels of PLD were decreased time-dependently during ceramide-induced apoptosis. Thus, ongoing investigations of the mechanism(s) mediating the action of ceramide on PLD activity and gene expression will contribute to enhanced understanding of apoptotic signaling pathway. Furthermore, our results provide new insight regarding potential regulatory mechanism between the two important lipid-mediated pathway of signal transduction, namely the ceramide signaling pathway and PLD signaling pathway in apoptosis.

\section{Acknowledgement}

This work was supported by a grant No. 96-0403-02-013 from Korea Science and Engineering Foundation.

\section{References}

Arends, M. J. and Wyllie, A. H. (1991) Apoptosis: mechanism and roles in pathology. Int. Rev. Exp. Pathol. 32: 223-354

Arscott, P. L., Knapp, J., Rymaszewski, M., Bartron, J. L., Bretz, J. D., Thompson, N. W. and Baker J. R. Jr. (1997) Fas (APO-1/, CD95)-mediated apoptosis in thyroid cells is regulated by labile protein inhibitor. Endocrinology 138: 50195027

Balboa, M. A., Firestein, B. L., Godson, C., Bell, K. S. and Insel, P. A. (1994) Protein kinase C $\alpha$ mediates phospholipase $D$ activation by nucleotides and phorbol ester in Madin-Darby canine kidney cells. Stimulation of phospholipase $D$ is independent of activation of polyphosphoinositide-specific phospholipase C and phospholipase A2 J. Biol. Chem. 269: 10511-10516

Ballou, L. R., Laulederkind, S. J. K., Rosloniec, E. F. and Raghow, R. (1996) Ceramide signaling and the immune response. Biochem. Biophy. Acta. 1301: 273-287

Bielawska, A., Crane, H. M., Loitta, D., Obsid, L. M. and Hannun, Y. A. (1993) Selectivity of ceramide-mediated biology. J. Biol. Chem. 268: 26226-26232

Bligh, E. G. and Dyer, W. J. (1959) A rapid method of total lipid extraction and purification. Can. J. Biochem. Physiol. 37: 911-919

Boesen-de Cock, J. G. R., Tepper, A. D., de Vries, E., van Blitterswijk, W. J. and Borst, J. (1998) CD95 (Fas/APO-1) induces ceramide formation and apoptosis in the absence of a functional acid sphingomyeliase. J. Biol. Chem. 273: 75607565

Bowman, E. P., Uhlinger, D. J. and Lambeth, J. D. (1993) Neutrophil phospholipase $\mathrm{D}$ is activated by a membraneassociated Rho family small molecular weight GTP-binding protein. J. Biol. Chem. 268: 21509-21512

Brown, H. A., Gutowski, S., Moomaw, C. R., Slaughter, C. and Sternweis, P. C. (1993) ADP-ribosylation factor, a small GTPdependent regulatory protein, stimulates phospholipase $D$ activity. Cell 75: 1137-1144

Brugg, B., Michel, P. P., Agid, Y. and Ruberg, M. (1996) ceramide induces apoptosis in cultured mesencephalic neurons. J. Neurochem. 66: 733-739

Clarke, P. G. H. (1990) Developmental cell death: Morphological diversity and multiple mechanism. Anat. Embryol. 181: $195-213$

Cockcroft, S., Thomas, G. M. H., Fensome, A., Geny, B., Cunningham, E., Gout, I., Hiles, I., Totty, N. F., Truong, O. and Hsuan, J. J. (1994) Phospholipase D: a downstream effector of ARF in granulocytes. Science 263: 523-526

Exton, J.H. (1990) Signaling through phosphatidylcholine 
breakdown. J. Biol. Chem. 265: 1-4

Exton, J. H. (1994) Phosphatidylinositol breakdown and signal transduction. Biochim. Biophys. Acta 1212: 26-42

Gamen, S., Marzo, I., Anel, A., Pineiro, A. and Naval, J. (1996) CPP32 inhibition prevents Fas-induced ceramide generation and apoptosis in human cells. FEBS lett. 390: 233-237

Gómez-Munoz, A., Martin, A., O'Brien, L. and Brindley, D. N. (1994) Cell-permeable ceramide inhibit the stimulation of DNA synthesis and phospholipse $D$ activity by phosphate and lysophosphatidate in rat fibroblast. J. Biol. Chem. 269: 89378943

Gómez-Munoz, A., Waggoner, D. W., O'Brien, L. and Brindley, D. N. (1995) Interaction of ceramides, sphingosine, and sphingosine 1-phosphate in regulating DNA synthesis and phospholipase D activity. J. Biol. Chem. 270: 26318-26325

Gulbins, E., Bissonnette, R., Mahboubi, A., Martin, S., Nishioka, W., Brunner, T., Baier, G., Baier-Bitterlich, G. B., Byrd, C., Lang, F., Kolesnick, R., Altman, A. and Green, D. (1995) Fasinduced apoptosis is mediated via a ceramide-initiated Ras signaling pathway. Immunity 2: 341-3511

Haimovitz-Freidman, A., Kan, C. C., Ehleiter, D., Persaud, R. S., McLoughlin, M., Fuks, Z. and Kolesnick, R. N. (1994) lonizing radiation acts on cellular membranes to generate ceramide and initiate apoptosis. J. Exp. Med. 180: 525-535

Hannun, Y. A. and Obeid, L. M. (1995) Ceramide: An intracellular signal for apoptosis. Trends Biochem. Sci. 20: 73-77

Hoffman, B. and Liebermann, D. A. (1994) Molecular controls os apoptosis: differentiation/growth arrest primary response genes, proto-oncogenes, and tumor suppressor gene as positive \& negative modulators. Oncogene 9: 1807-1812

Jarvis, W. D., Fornari, F. A. Jr., Browning, J. L., Gewirtz, D. A., Kolesnick, R. N. and Steven, G. (1994) Attenuation of ceramideinduced apoptosis by diglycerid in human myeloid leukemia cells. J. Biol. Chem. 269: 31685-31692

Jarvis, W. D., Turner, A. J., Povirk, L. F., Traylor, R. S. and Grant, S. (1994) Induction of apoptotic DNA fragmentation and cell death in HL-60 human promyelocytic leukemia cells by pharmacological inhibitors of protein kinase C. Cancer Res. 54: 1707-1714

Jones, M. and Murray, A. W. (1995) Evidence that ceramide selectively inhibits protein kinase $\mathrm{C}$-a translocation and modulates bradykinin activation of phospholipase D. J. Biol. Chem. 270: 5007-5013

Kaipia, A., Chun, S. Y., Eisenhauer, K. and Hsueh, A. J. W. (1996) Tumor necrosis factor-a and its second messenger, ceramide, stimulate apoptosis in cultured ovarian follicles. Endocrinology 137: 4864-4870

Klein, J., Chalifa, V., Liscovitch, M. and Loffelholz, K. (1995) Role of phospholipase $D$ activation in nervous system physiology and pathophysiology. J. Neurochem. 65: 1445-145

Kolesnick, R. N. and Fuks, Z. (1995) Ceramide: a signal for apoptosis or mitogenesis? J. Exp. Med. 1815: 1949-1952

Kolesnick, R. N. and Glode, D. W. (1994) The sphingomyelin pathway in tumor necrosis factor and interleukin-1 signaling.
Cell 77: $325-328$

Kolesnick, R. N., Haimovitz-Freidman, A. and Fuks, Z. (1994) The sphingomyelin signal transduction pathway mediates apoptosis for tumor necrosis factor, Fas, and ionizing radiation. Biochem. Cell. Biol. 72: 471-474

Kotani, T., Aratake, Y., Hirai, K., Fukazawa, Y., Sata, H. and Ohtaki, S. (1995) Apoptosis in thyroid tissue from patients with Hashimoto's thyroiditis. Autoimmunity 20: 231-236

Lejeune, C., Taton, M., Collyn, L., Rocmans, P., Dumont, J. E. and Mockel, J. (1996) Regulation and metabolic role of phospholipase $\mathrm{D}$ activity in human thyroid and cultured dog thyrocytes. J. Clin. Endocrinol. Metab. 81: 3526-3534

Liscovitch, M. (1991) Signal-dependent activation of phosphatidylcholine hydrolysis: role of phospholipase D. Biochem. Soc. Trans. 19: 402-407

Liscovitch, M. and Cantley, L. C. (1995) Signal transduction and membrane traffic: the PITP/phospholipase D connection. Cell 81: 659-662

Malcolm, K. C., Ross, A. H., Quu, R. G., Symons, M. and Exton, J. H. (1994) Activation of rat liver phospholipase D by the small GTP-binding protein RhoA. J. Biol. Chem. 269: 25951-25954

Mori, K., Stone, S., Braverman, L. E. and DEVito, J. (1996) Effects of ceramide and protein kinase $C$ on the regulation of type I 5'-deiodiase in FRTL-5 rat thyroid cells. Endocrinology 137: 4994-4999

Morris, R. G., Hargreaves, A. D., Duvall, E. and Wyllie, A. H. (1984) Hormone-induced cell death. 2. Surface changes in thymocytes undergoing apoptosis. Am. J. Pathol. 115: 426436

Nakamura, Y., Nakashima, S., Ojio, K., Banno, Y., Miyata, H. and Nozawa, Y. (1996) Ceramide inhibits IgE-mediated activation of phospholipase $\mathrm{D}$, but not of phospholipase $\mathrm{C}$, in rat basophilic leukemia (RBL-2H3) cells. J. Immunol. 156: 256262

Nishuizuka, Y. (1995) Protein kinase $C$ and lipid signaling for sustained cellular response. FASEB J. 9: 484-496

Obeid, L. M., Linardic, C. M., Karolak, L. A. and Hannun, Y. A. (1993) Programmed cell death induced by ceramide. Science 259: $1769-1771$

Pushkareva, M., Obeid, L. M. and Hannun, Y. A. (1995) Ceramide: An endogenous regulator of apoptosis and growth suppression. Immunol. Today 16: 294-297

Santana, P., Llanes, L., Hernandez, I., Gallardo, G. and Quintana, J. (1995) Ceramide mediates tumor necrosis factor effects on P450-aromatase activity in cultured granulosa cell. Endocrinology 136: 2345-2348

Spiegel, S. and Milestien, S. (1996) Sphingoid bases and phospholipase D activation. Chem. Physic. Lipid 80: 27-36

Stacey, N. H., Bishop, C. J., Halliday, J. W., Cooksley, W. G., Powell, L. W. and Kerr, J. F. (1985) Apoptosis as the mode of cell death in antibody-dependent lymphocytotoxicity. J. Cell. Sci. 74: 169-179

Tamura, M., Kimura, H., Koji, T., Tominaga, T., Ashizawa, K., Kiriyama, T., Yokoyama, N., Yoshimura, T., Eguchi, K., Kakane, 
P. K. and Nagataki, S. (1998) Role of apoptosis of thyrocytes in a rat model of goiter. A possible involvement of Fas system. Endocrinology 139: 3626-3653

Tanimoto, C., Hirakawa, S., Kawasaki, H., Hayakawa, N. and Ohtaki, S (1995) Apoptosis in thyroid diseases: a histochemical study. Endocr. J. 42: 193-201

Tepper, A. D., Boesen-de Cock J. G. R., de Vries, E., Borst, J. and van Blitterswijk, W. J. (1997) CD95/Fas-induced ceramide formation proceeds with slow kinetics and in not blocked by caspase-3/CPP32 inhibition. J. Biol. Chem. 272: 24380-24312

Tepper, C. G., Jayadev, S., Liu, B., Bielawska, A., Wolff, R., Yonehara, S., Hannun, Y. A. and Seldin, M. F. (1995) Role for ceramide as an endogenous mediator of Fas-induced cytotoxicity. Proc. Nat'l. Acad. Sci. USA 92: 8443-8447

Testi, R. (1996) Sphingomyelin break down and cell fate. Trends Biochem. Sci. 21: 468-471

Venable, M. E., Bielawska, A. and Obeid, L. M. (1996) Ceramide inhibits phospholipase D in a cell-free system. J. Biol. Chem. 271: $24800-24805$

Venable, M. E., Blobe, G. C. and Obied, L. M. (1994) Identifi- cation of a defect in the phospholipase D/diacylglycerol pathway in cellular senescence. J. Biol. Chem. 269: 2604026044

Williams, G. T. and Smith, C. A. (1993) Molecular regulation of apoptosis: genetic controls on cell death. Cell 74: 777-779

Witty, J. P., Bridgham, J. T. and Johnson, A. L. (1996) Induction of apoptotic cell death in hen granulosa cell by ceramide. Endocrinology 137: 5269-5277

Wyllie, A. H. (1980) Glucocoricoid-induced thymocyte apoptosis is associated with endogenous endonuclease activation. Nature 284: $555-556$

Wyllie, A. H. (1995) The genetic regulation of apoptosis. Curr. Opin, Genet. Dev. 5: 97-104

Wyllie, A. H., Kerr, J. F. R. and Currie, A. R. (1980) Cell death: the significance of apoptosis. Int. Rev. Cytol. 68: 251-255

Yoshimura, S., Sakai, H., Ohguchi, K., Nakashima, S., Banno, Y., Nishimura, Y., Sakai, N. and Nozawa, Y. (1997) Changes in the activity and mRNA levels of phospholipase $D$ during ceramide-induced apoptosis in rat C6 glial cells. J. Neurochem. 69: 713-720 